\title{
A New Genus of Crickets (Orthoptera: Gryllidae) in Mid-Cretaceous Myanmar Amber
}

\author{
George Poinar, Jr. ${ }^{a *}$, You Ning Su ${ }^{b}$ and Alex E. Brown ${ }^{c}$ \\ aDepartment of Integrative Biology, Oregon State University, Corvallis, OR 97331, USA. \\ ${ }^{b}$ Australian National Insect Collection, CSIRO, Clunies Ross St, Acton, ACT 2601, Canberra, Australia. \\ ${ }^{\text {b}} 629$ Euclid Avenue, Berkeley, CA 94708, USA. \\ *Corresponding Author: George Poinar, Jr. Email: poinarg@science.oregonstate.edu \\ (C) The Author(s) 2020
}

\begin{abstract}
Crickets (Orthoptera: Grylloidea) are a highly diverse and successful group that due to their chirping are often heard more often than they are seen. Their omnivorous diet allows them to exist in a variety of terrestrial habitats around the world. In some environments, cricket populations can build up and become plagues, resulting in significant damage to seedling crops. A new genus and species of cricket, Pherodactylus micromorphus gen. et sp. nov. (Orthoptera: Gryllidae) is described from mid-Cretaceous Myanmar amber. The new genus is characterized by the following features: head without prominent bristles, pronotum longer than wide, middle of pronotal disk with two distinct large dark "eyespots", fore leg robust and 3 apical spurs arranged on inner side of fore leg tibia. Shed portions of a lizard skin adjacent to the specimen reveal possible evidence of attempted predation.
\end{abstract}

ARTICLE HISTORY

Received 28 December 2019

Revised 10 January 2020

Accepted 15 January 2020

\section{KEYWORDS}

Gryllidae

mid-Cretaceous

Myanmar amber

comparative morphology

Pherodactylus micromorphus cricket

\section{Introduction}

Crickets (Orthoptera: Grylloidea) are an extremely diverse and successful group and occur globally except at the Poles. They are omnivorous and survive in most available terrestrial habits including in the ground, in surface litter, under bark and on foliage at many elevations. Some live in coastal habitats and are even capable of swimming. They can be solitary or demonstrate various stages of gregariousness. Some are economically important due to crop damage and others are pests as a result of their continuous chirping (Blatchley, 1920; Capinera et al., 2004; Otte \& Alexander, 1983; Rentz, 1996).

Most crickets have antennae as long or longer than their bodies, auditory tympana at the base of their fore tibia, enlarged hind femora that allow them to quickly jump, and straight or slightly curved ovipositors through which eggs are mostly deposited singly in the ground. The family Gryllidae is separated into a number of subfamilies based on various physical features (Blatchley, 1920; Capinera et al., 2004; Otte \& Alexander, 1983; Rentz \& $\mathrm{Su}, 2019)$. The present paper describes a last instar female cricket in Myanmar amber. While the specimen is in its last instar, it possesses all of the adult features except those of the reproductive system and is considered worthy of description for this reason as well as to the rarity of crickets in amber.

\section{Materials and methods}

The specimen originated from the Noije Bum 2001 Summit Site mine excavated in the Hukawng Valley and located southwest of Maingkhwan in Kachin State $\left(26^{\circ} 20^{\prime} \mathrm{N}, 9^{\circ} 36^{\prime} \mathrm{E}\right)$ in Myanmar (Cruickshank \& Ko, 2003) (Figs. 1, 2 and 3). Many Grylloidea samples were collected from the site (Zhang, 2017). Based on paleontological evidence, this site was dated to the late Albian of the Early Cretaceous (Cruickshank \& Ko, 2003), placing the age at 97 to $110 \mathrm{Ma}$. A more recent study using $\mathrm{U}-\mathrm{Pb}$ zircon dating determined the age to be $98.79 \pm 0.62 \mathrm{Ma}$ or at the Albian/Cenomanian boundary (Shi et al., 2012). Nuclear magnetic resonance (NMR) spectra and the presence of araucaroid wood fibers in amber samples from the Noije Bum 2001 Summit Site indicate an araucarian tree source for the amber (Poinar Jr et al., 2007). 


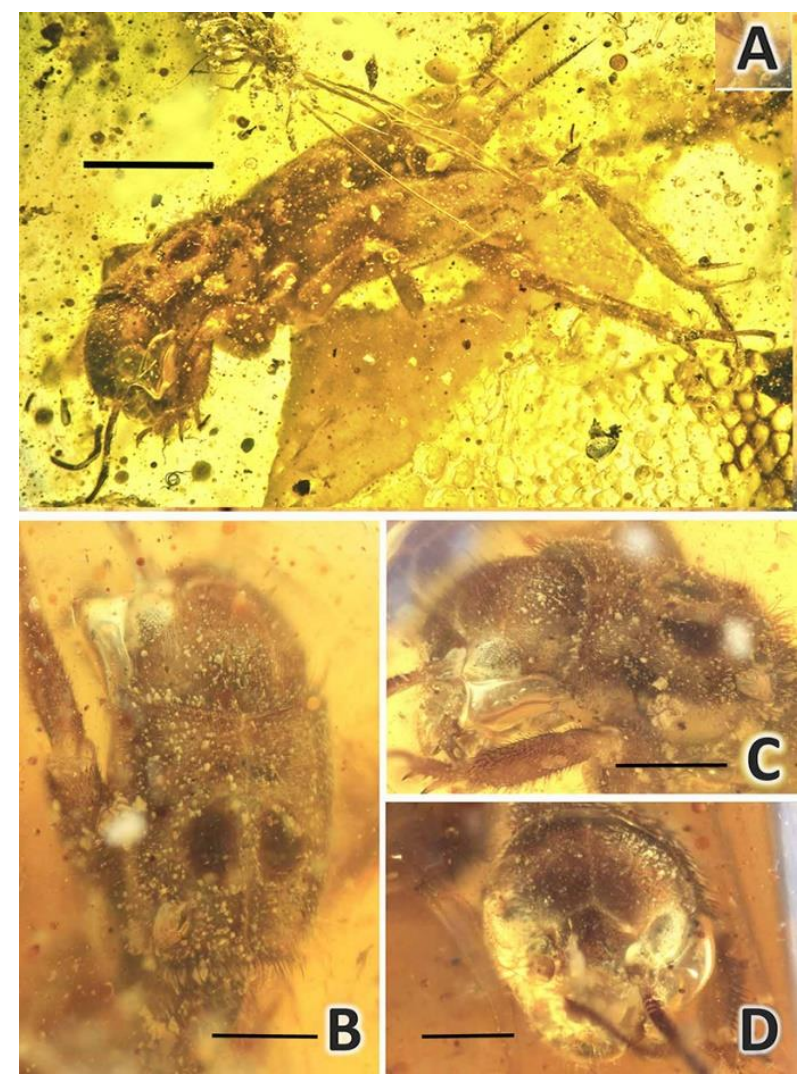

Fig. 1. Pherodactylus micromorphus Poinar et al., sp. nov. A. Immature female embedded in amber.Scale bar $=1.0 \mathrm{~mm}$. Note portion of lizard skin in bottom right. $\mathbf{B}$. Dorsal view, head and pronotum. Scale bar $=0.6 \mathrm{~mm}$. C. Lateral view, head and pronotum. Scale bar $=0.7 \mathrm{~mm}$. D. Frons. Scale bar $=0.5 \mathrm{~mm}$.
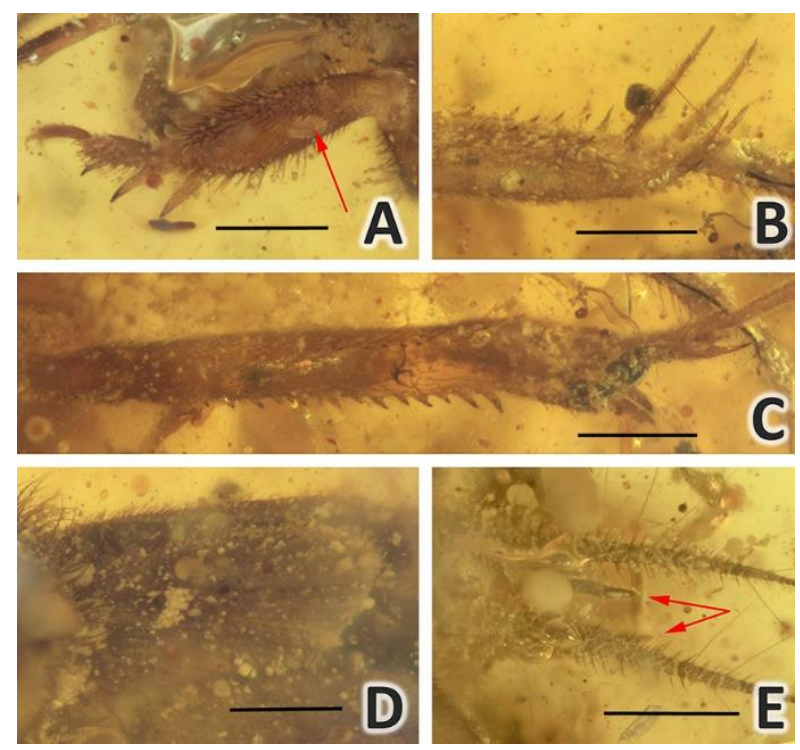

Fig. 2. Pherodactylus micromorphus Poinar et al., sp. nov. A. Left fore tibia and tarsus, note tympanum (arrow). Scale bar $=0.5 \mathrm{~mm}$. B. Apical spurs on right hind tibia. Scale bar $=0.6 \mathrm{~mm}$. C. Left hind tibia in dorsal view. Scale bar $=0.3 \mathrm{~mm}$. D. Immature hindwings. Scale bar $=0.4 \mathrm{~mm}$. E. Cercus and undeveloped ovipositor (arrows). Scale bar $=0.7 \mathrm{~mm}$.
Observations and photographs were made with following equipment: a Nikon SMZ-10 R stereoscopic microscope and Nikon Optiphot compound microscope with magnifications up to $800 \mathrm{X}$; a Leica M205A microscope; and a BK Plus Lab System featuring a P-51 Cam lift and an Infinity Optics K2 Long Distance Microscope. Helicon Focus Pro X64 was used to stack photos for better depth of field.

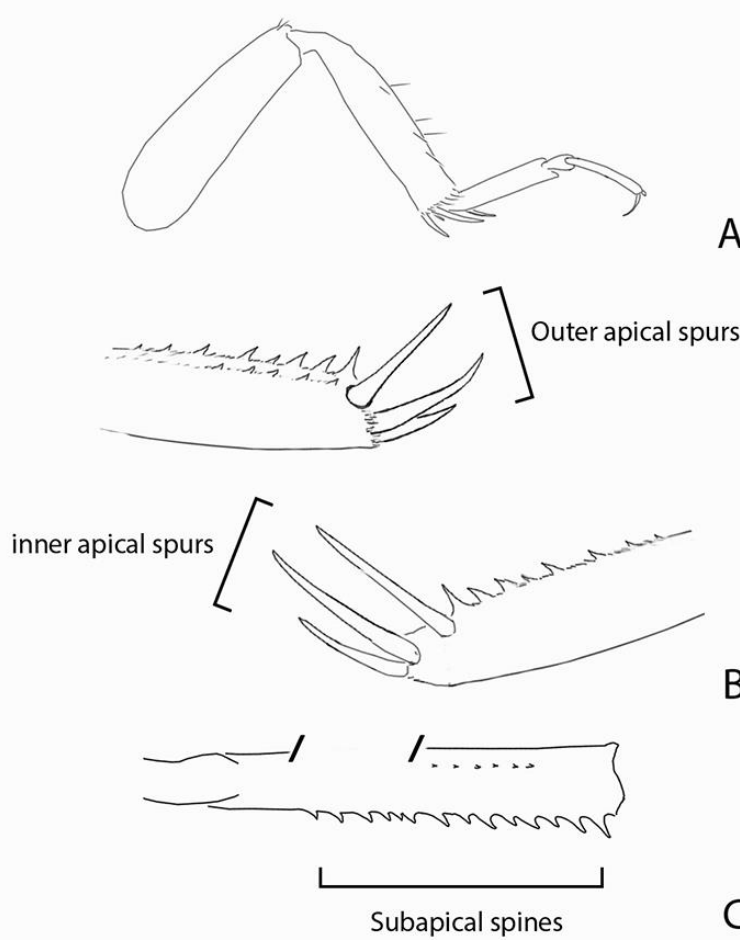

Fig. 3. Pherodactylus micromorphus Poinar et al., sp. nov. A. Left middle leg; note four inner tibia apical spurs. B. Left hind leg; note three inner apical spurs. C. Right hind tibia, note 14 inner subapical spines.

The terminology followed in the present study is an adaptation of Rentz \& Su (2019) on general morphology and Leubner et al. (2017) on endoskeleton, with some modification and additions.

\section{Results}

Characters presented by Brues et al. (1954), Otte \& Alexander (1983), Vickery (1977), Rentz (1996) and Rentz \& Su (2019) were used to assign the specimen to the family Gryllidae. These characters include: head without dorsal bristles, tympana on the outer fore tibia, tarsi 3-segmented with $1^{\text {st }}$ tarsal segment longer that the other two combined, hind tibia shorter than hind femur; long terminal spurs on hind tibia with spines on proximal portion of hind tibia.

Orthoptera Latreille, 1793

Family Gryllidae Laicharting, 1781

LSID

Type genus Pherodactylus gen. nov. 
Diagnosis: Overall body shape and color typical of the Gryllidae (Figs. 1 and 7). Body mostly brown, covered with short fine hairs and bearing undeveloped wing pads. Head without prominent bristles (Fig. 1d). Pronotum longer than wide; middle of pronotal disk with two distinct large dark "eyespots" (Fig. 1b). Foreleg robust, with 3 apical spurs arranged on inner side of fore leg tibia (Figs. 2a, 4a).

Genera included: type genus only.

LSID for the new genus Pherodactylus:

urn:lsid:zoobank.org:act:2CF437AF-310E-4C6D-890689A8A8700BB9

Type species: Pherodactylus micromorphus gen. et sp. nov. here designated.

Etymology. The generic name is taken from the Greek "phero"= to bear, carry and the Greek "daktylos" = finger, in reference to the modified forelegs of the specimen.

Diagnosis: As for family (by monotypy)

Included species: type species only.

Pherodactylus micromorphus sp. nov. (Figs. 1-7)

LSID for the new species is Pherodactylus micromorphus:

urn:lsid:zoobank.org:act:C1110413-A29B-4DE8-

B167-A967947887A4

Etymology. The specific epithet is from the Greek "mikros" = small and the Greek "morpho" = form in reference to the small size of the fossil.

Type material. Holotype female deposited in the Poinar's amber collection (accession B-O-12) maintained at Oregon State University.

Type locality. Hukawng Valley southwest of Maingkhwan in Kachin State $\left(26^{\circ} 20^{\prime} \mathrm{N}, 9^{\circ} 36^{\prime} \mathrm{E}\right)$, Myanmar.

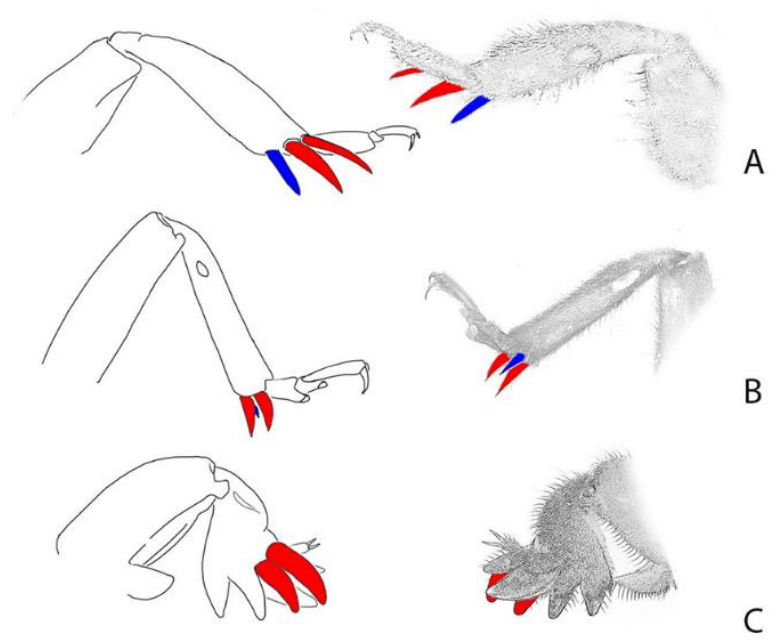

Fig. 4. Comparison of left foreleg of crickets; note the arrangement of tibia apical spurs A. Pherodactylus micromorphus Poinar et al., sp. nov. B. Tarbinskiellus portentosus (Lichtenstein). C. Gryllotalpa australis
Erichson.

LSID for the publication is:

urn:1sid:zoobank.org:pub:55D55A4A-1A7C-425C-

8C01-7AC7C2EAFAEC

\section{Description}

Juvenile female (Figs. 1, 2 and 7). Body length, $4.5 \mathrm{~mm}$ (exclusive of cerci and head appendages). The specimen is essentially complete except for the tips of the antennae.

Head. Sub-prognathous, slightly flattened dorsoventrally; length, $1.6 \mathrm{~mm}$, width $1.3 \mathrm{~mm}$; antenna incomplete, unable to determine length; remaining portion of antennae many-segmented; eyes small, 0.5 $\mathrm{mm}$ in diameter, barely protruding from head outline; 3 ocelli arranged in a triangle. Head lacking prominent bristles. Dorsum and side of head as in Figs. 1c,d.

Pronotum. Pronotum elongate, $1.4 \mathrm{~mm}$ long, 1.2 times as long as wide; front of pronotum 1.2 times as wide as back; three times as long as head, $1.5 \mathrm{~mm}$ in width; with a pair of roundish marks on the pronotal disk (Fig. 1b). Lateral lobe dark above, pale below (Fig. 1c).

Legs (Figs. 2-4). Fore leg moderately robust, fore femur $0.9 \mathrm{~mm}$ long, flattened; fore tibia, $1.2 \mathrm{~mm}$ long; apex of fore tibia bearing 3 dactyls, all approximately $315 \mu \mathrm{m}$ long (Fig. 2a); tympana present in outer side only (Fig. 2a, arrow), inner tympana absent, tibia laterally compressed with three apical spurs arranged on inner side of tibia (Fig. 4a). Hind tibia $1.8 \mathrm{~mm}$ in length, with 8 terminal spurs (lengths, $315 \mu \mathrm{m}, 540 \mu \mathrm{m}, 612 \mu \mathrm{m}, 675$ $\mu \mathrm{m}, 225 \mu \mathrm{m}, 315 \mu \mathrm{m}, 405 \mu \mathrm{m}, 630 \mu \mathrm{m})$ positioned as shown in Fig. 2b and Fig. 7; hind femur $2.8 \mathrm{~mm}$ in length; middle leg not especially modified, middle tibia with four apical spurs; hind leg femur covered with short fine hairs; femur III, $3 \mathrm{~mm}$; left hind tibia III, $1.8 \mathrm{~mm}$, serrated with spines on both the inner and outer margins (Fig. 2c), without a moveable subapical spur.

Wings. The visible wings are undeveloped hindwings (Fig. 2d), the forewings (tegmina) are not shown but presumably are located near the base of the hind wings. Undeveloped hind wing length, $1.3 \mathrm{~mm}$.

Abdomen. Length, $2.2 \mathrm{~mm}$; cerci $1.9 \mathrm{~mm}$ long, bearing long stiff setae; immature ovipositor short, $0.9 \mathrm{~mm}$ in length.

Comments: This genus is proposed to accommodate a single fossil species from the amber mines in northern Myanmar. It represents one of the most distinctive groups of the Grylloidea, characterized by having an enlarged pronotum with two "eyespots" on the pronotal 
disk. The fore legs seem to be specialized for a function that we have been unable to determine.

The habitus of the type species (Fig. 1a) bears a superficial resemblance to a mole cricket (Gryllotalpoidea).

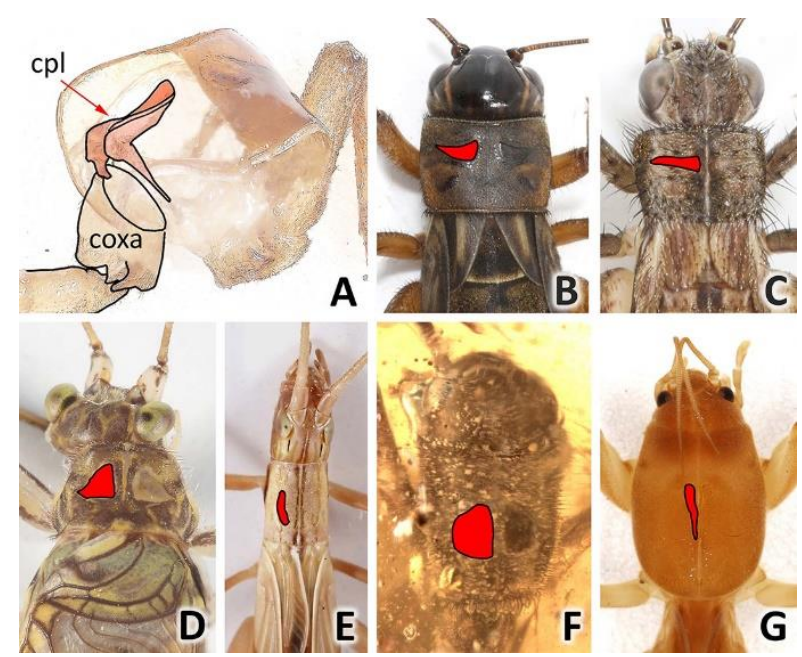

Fig. 5. Comparison of the pronotum of crickets; note the "eyespots" (red areas). A. Cryptopleura (cpl) of Gymnogryllus sp., note association with the coxa. B. Teleogryllus commodus (Walker). C. Bobilla kindyerra Otte and Alexander.D. Pseudotrigonidium australis (Chopard), DCF Rentz photo. E. Oecanthus rufescens Serville, DCF Rentz photo. F. Pherodactylus micromorphus Poinar et al., sp. nov. G. Gryllotalpa australis Erichson.

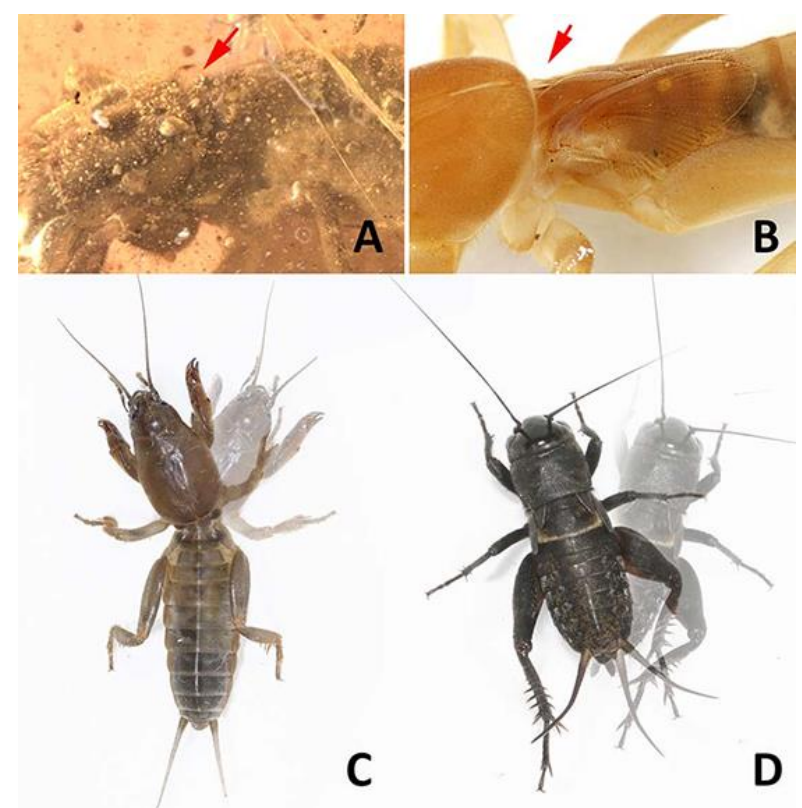

Fig. 6. Comparison of the mesothorax of crickets in relation to the movement of the thorax. Arrows shows junction between pro- and mesothorax.A. Pherodactylus micromorphus Poinar et al., sp. nov. B, C. Gryllotalpa australis Erichson, D. Teleogryllus commodus (Walker).

However, comparison of the morphological characters of the two groups (Figs. 4, 5) suggests that the fossil cricket is actually more closely related to the true crickets (Grylloidea) than to mole crickets. The only specimen of the type species, a last instar female, is tentatively placed in Gryllinae, but the very distinct characters and thoracic muscle arrangement suggests that it may belong to a related group of Gryllidae. The presence of undeveloped hindwings (Fig. 2d) and ovipositor (Fig. 2e) is the key to immediate recognition that this is an immature cricket. Comparison of the characters in Fig. 4 indicates that Pherodactylus gen. nov. may be the only known Grylloidea genus bearing modified apical spurs on the fore tibia.

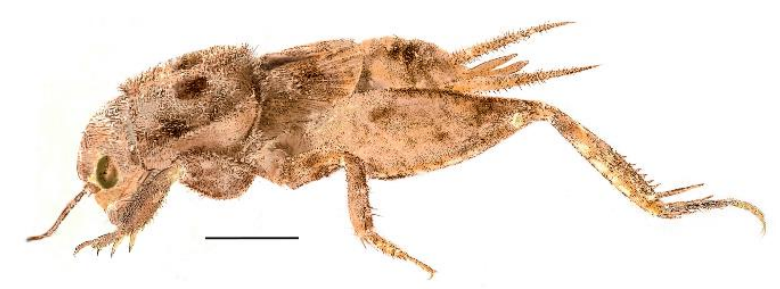

Fig. 7. Morphological reconstruction by PhotoShop ${ }^{\circledR}$ of Pherodactylus micromorphus Poinar et al., sp. nov.Note that the antennae are incomplete. Scale bar $=1.0 \mathrm{~mm}$.

\section{Discussion}

It would appear that the fossil cricket was a grounddwelling, rather than a soil-inhabiting species based on the following rationale. The large round eyes are characteristic of ground-dwelling crickets. Subterranean species like mole crickets have much smaller eyes (see Figs. 1, 5 and 7). The left and right wing pads being close together suggests that $P$. micromorphus has a flexible movement as in mole crickets (Fig. 6). Mole cricket fore legs (Fig. 4c) have greatly modified spurs and tarsi that are used for digging in soil. The slender apical spurs of $P$. micromorphus do not indicate a modification for digging in soil but they may be used for raking.

The "eyespots" on the pronotum of crickets, referred to as "tear-shaped structures" in Otte \& Alexander (1983) are "cryptopleura" pleurallamelle in Voss (1905). These are smooth surfaced areas where the internally exposed cryptopleura contacts the pronotum from the inside Leubner et al. (2017). The enlarged pronotum with large contact areas of cryptopleura (Fig. 5) indicate larger muscles associated with the coxa (Voss, 1905), which provides a mechanical advantage for moving the front legs more powerfully or rapidly. Additionally, the shape of the pronotum of $P$. micromorphus is more like 
grylloid crickets than it is to the gryllotalpines. The elongate pronotum of gryllotalpines (Fig. $5 \mathrm{~g}$ ) seems to contain more muscles for digging and it is more flexible than the rigid, quadrate structure seen in grylloids (compare Figs. 6c, d).

The reptilian scales adjacent to Pherodactylus micromorphus gen. et sp. nov. (Fig. 1A) were identified as those of a lizard that may have been attempting to prey on the cricket.

The Grylloidea was the first lineage to diversify within Ensifera, starting in the Triassic and continuing throughout the Mesozoic (Heads \& Leuzinger, 2011; Song et al., 2015), with the Infraorder Gryllidea extending to the Permian (Rasnitsyn, 2002). Pherodactylus micromorphus gen. et sp. nov. is similar to the Gryllidae in all aspects except having an enlarged pronotum with large contact areas of cryptopleura. For the present, it is assigned to the subfamily Gryllinae.

\section{Acknowledgments}

Dr. D.C.F. Rentz is thanked for providing images of various crickets and helpful suggestions during the preparation of this paper.

\section{References}

Blatchley, W. S. (1920). Orthoptera of Northeastern America: With Especial Reference to the Faunas of Indiana and Florida. Berlin, Germany: Nature.

Brues, C. T., Melander, A. L., \& Carpenter, F. M. (1954). Classification of Insects. Bulletin of the Museum of Comparative Zoology, 108, 1-917.

Capinera, J. L., Scott, R. D., \& Walker, T. J. (2004). Field Guide to Grasshoppers, Crickets, and Katydids of the United States. Ithaca, New York, United States: Cornell University Press.

Cruickshank, R. D., \& Ko, K. (2003). Geology of an amber locality in the Hukawng Valley, Northern Myanmar. Journal of Asian Earth Sciences, 21(5), 441-455. https://doi.org/10.1016/s1367-9120(02)000445

Heads, S., \& Leuzinger, L. (2011). On the placement of the Cretaceous orthopteran Brauckmannia groeningae from Brazil, with notes on the relationships of Schizodactylidae (Orthoptera, Ensifera). ZooKeys, 77, 17-30. https://doi.org/10.3897/zookeys.77.769

Leubner, F., Bradler, S., \& Wipfler, B. (2017). The thoracic morphology of the wingless dune cricket Comicus calcaris (Orthoptera: Schizodactylidae): Novel apomorphic characters for the group and adaptations to sand desert environments. Arthropod Structure \& Development, 46(4), 449-461. https://doi.org/10.1016/j.asd.2017.03.006

Otte, D., \& Alexander, R. D. (1983). The Australian Crickets (Orthoptera: Gryllidae). Philadelphia, PA: Academy of Natural Sciences of Philadelphia.

Poinar Jr, G., Lambert, J. B., \& Wu, Y. (2007). Araucarian source of fossiliferous Burmese amber: spectroscopic and anatomical evidence. Journal of the Botanical Research Institute of Texas, 1(1), 449-455.

Rasnitsyn, A.P., \& Quicke, D.L.J. (2002). History of Insects. Dordrecht: Kleuver Academic Publishers.

Rentz, D., \& Su, Y. N. (2019). Guide to Crickets of Australia. Clayton, Australia: CSIRO Publishing.

Rentz, D. C. F. (1996). Grasshopper country: the abundant orthopteroid insects of Australia. Sydney: University of New South Wales Press.

Shi, G., Grimaldi, D. A., Harlow, G. E., Wang, J., Wang, J., Yang, M., \& Li, X. (2012). Age constraint on Burmese amber based on U-Pb dating of zircons. Cretaceous Research, 37, 155-163. https://doi.org/10.1016/j.cretres.2012.03.014

Song, H., Amédégnato, C., Cigliano, M. M., DesutterGrandcolas, L., Heads, S. W., Huang, Y., Whiting, M. F. (2015). 300 million years of diversification: Elucidating the patterns of orthopteran evolution based on comprehensive taxon and gene sampling. Cladistics, 31(6), 621-651. https://doi.org/10.1111/cla.12116

Vickery, V. R. (1977). Taxon ranking in Grylloidea and Gryllotalpoidea. Memoirs of the Lyman Entomological Museum and Research Laboratory, 4, 32-43.

Voss, F. (1905). Über den Thorax von Gryllus domesticus. Erster Teil. Das Skelett. ZWiss Zool, 78, 268-514.

Zhang, W. (2017). The Fossil Insects and other Invertebrates in Amber. Peking, China: Chongqing da xue chu ban she. 
Publisher's note: Eurasia Academic Publishing remains neutral with regard to jurisdictional claims in published maps and institutional affiliations.

Open Access This article is licensed under a Creative Commons Attribution-NoDerivatives 4.0 International (CC BY-ND 4.0) licence, which permits copy and redistribute the material in any medium or format for any purpose, even commercially. The licensor cannot revoke these freedoms as long as you follow the licence terms. Under the following terms you must give appropriate credit, provide a link to the license, and indicate if changes were made. You may do so in any reasonable manner, but not in any way that suggests the licensor endorsed you or your use. If you remix, transform, or build upon the material, you may not distribute the modified material.

To view a copy of this license, visit https://creativecommons.org/licenses/by-nd/4.0/. 